\title{
HUBUNGAN LINGKUNGAN KERJA DAN KONSEP DIRI DENGAN BURNOUT PADA ANGGOTA BRIGADE MOBILE KEPOLISIAN DAERAH MEDAN SUMATERA UTARA. Oleh
}

\author{
Wayan \\ E-mail: wyan@gmail.com
}

\begin{abstract}
This study aims to determine the relationship between work environment and self concept with burnout. The study was conducted at the mobile brigade police of the Republic of Indonesia North Sumatra in the city of Medan. The number of respondents in this study were 196 members of the mobile brigade with non probability sampling techniques. Based on Spearman rank data analysis obtained a significant level between work environment (X1) with burnout (Y) with a significant value of $0,000<0,05$, meaning that there is a partial relationship between work environment and burnout. While the relationship of self-concept (X2) with burnout (Y) with a significant value of $0,000<0.05$. This proves that there is a partial relationship between selfconcept and burnout. While the significance level of the work environment (X1) and self-concept (X2) with burnout (Y) with a significant value of $0,000<0,05$ are related simultaneously, then the hypothesis in this study is accepted. The correlation between work environment and self concept with burnout on members of the mobile brigade in the city of Medan, North Sumatra is $56 \%$.
\end{abstract}

Keywords: Burnout, work environment, self-concept.

Abstrak. Penelitian ini bertujuan untuk mengetahui hubungan lingkungan kerja dan konsep diri dengan burnout. Penelitian dilaksanakan di brigade mobile kepolisian daerah Medan Sumatera Utara. Jumlah responden dalam penelitian ini adalah 196 anggota brigade mobile dengan teknik pengambilan sampel non probability sampling. Berdasarkan analisis data rank spearman diperoleh taraf signifikan antara lingkungan kerja (X1) dengan burnout (Y) dengan nilai signifikan 0,000 < 0,05 , artinya membuktikan bahwa terdapat hubungan secara parsial lingkungan kerja dengan burnout. Sedangkan hubungan konsep diri (X2) dengan burnout (Y) dengan nilai signifikan 0,000 $<0,05$. Hal tersebut membuktikan bahwa terdapat hubungan secara parsial konsep diri dengan burnout. Sedangkan taraf signifikasi lingkungan kerja (X1) dan konsep diri (X2) dengan burnout (Y) dengan nilai signifikan 0,000 $<0,05$ berhubungan secara simultan, maka hipotesis dalam penelitian ini diterima. Besar korelasi hubungan lingkungan kerja dan konsep diri dengan burnout pada anggota satuan brigade mobile kepolisian daerah Medan Sumatera Utara sebesar 56\% .

Kata Kunci: Burnout, lingkungan kerja, konsep diri.

38 | Psychophedia Jurnal Psikologi Universitas Buana Perjuangan Karawang 


\section{Pengantar}

Salah satu persoalan yang sering muncul yang berkaitan dengan diri individu di dalam menghadapi tuntutan pekerjaan yang semakin tinggi dan persaingan yang keras di tempat kerja karyawan itu adalah stres. Stres yang berlebihan akan berdampak pada terhadap kemampuan individu berhubungan dengan lingkungannya secara normal. Stres yang dialami individu dalam jangka waktu yang lama dengan intensitas yang cukup tinggi akan mengakibatkan individu yang bersangkutan menderita kelelahan, baik fisik maupun mental. Menurut Leatz dan Stolar (dalam Rosyid \& Farhati, 1996) keadaan seperti ini disebut dengan burnout, kelelahan fisik, mental dan emosional yang terjadi karena stres diderita dalam jangka waktu yang cukup lama, di dalam situasi yang menuntut keterlibatan emosional yang tinggi.

Baron dan Greenberg (2003) mengatakan bahwa burnout adalah suatu sindrom kelelahan emosional, fisik, dan mental, berhubungan dengan rendahnya perasaan harga diri, disebabkan penderitaan stres yang intens dan berkepanjangan. Maslach (dalam Ema, 2004) mengungkapkan burnout berdampak bagi individu, orang lain, dan organisasi. Dampak pada individu terlihat adanya gangguan fisik seperti sulit tidur, rentan terhadap penyakit, munculnya gangguan psikosomatik, maupun gangguan psikologis yang meliputi penilaian yang buruk terhadap diri sendiri yang dapat mengarah pada terjadinya depresi.

Permasalahan burnout sering terjadi pada pekerja yang memberikan pelayanan jasa pada masyarakat, seperti guru, perawat dan polisi. Pada organisasi brigade mobile kepolisian daerah Sumatera Utara juga mengalami permasalahan yang berhubungan dengan sumber daya manusia, yang mana anggota brigade mobile juga mengalami kondisi burnout. Brigade mobile merupakan organisasi elit militer yang dimiliki oleh negara Indonesia, karena fungsi dari satuan brigade mobile adalah menjaga keamanan Bangsa Indonesia maka anggota brigade mobile dituntut untuk menunjukan performance kinerja yang baik dan memiliki jiwa pengabdian dalam bekerja, sehingga dalam bekerja kepentingan masyarakat menjadi yang terpenting dan terutama untuk memberikan pelayanan yang terbaik bagi masyarakat.

Aspek-aspek burnout menurut Maslach (dalam Dorman, 2003) yaitu emotional exhaustion, depersonalitation, low personal accomplistment. Dalam penelitian ini untuk mengukur burnout digunakan alat ukur pengukuran yang bernama The Maslach Burnout Inventory (MBI).

Baron dan Greenberg (1995) menjelaskan bahwa burnout yang dialami seorang pekerja selain dipengaruhi oleh faktor internal juga dipengaruhi oleh faktor eksternal dalam organisasi. Faktor internal meliputi jenis kelamin, usia, konsep diri dan harga diri, sedangkan faktor eksternal meliputi salah satunya lingkungan kerja. Menurut Wineman (dalam Syafika, 2004) setiap lingkungan kerja selalu meliputi kondisi lingkungan fisik dan lingkungan psikologis. Lingkungan fisik merupakan keadaan ruangan beserta perlengkapan yang mendukung, sedangkan lingkungan psikologis merupakan kondisi organisasi dan interaksi sosial di dalamnya. Taiwo (2010) menyatakan bahwa lingkungan kerja adalah 
segala sesuatu, kejadian, orang-orang dan lainnya yang mempengaruhi cara orangorang bekerja.

\section{Landasan Teori}

\section{Lingkungan Kerja}

Menurut Noah dan Steve (2012), lingkungan kerja adalah keseluruhan hubungan yang terjadi dengan karyawan di tempat kerja. Segala sesuatu yang berada di tempat kerja merupakan lingkungan kerja. Gitosudarmo (2000) menyatakan lingkungan kerja adalah segala sesuatu yang ada di sekitar pekerja yang dapat mempengaruhi karyawan dalam bekerja meliputi pengaturan penerangan, pengontrolan suara gaduh, pengaturan kebersihan tempat kerja dan pengaturan keamanan tempat kerja.

Aspek-aspek lingkungan kerja yang Stewart and Stewart (1991) yaitu kondisi fisik dan kondisi psikologis lingkungan kerja. Menurut Simanjuntak (2003) aspek-aspek lingkungan kerja yaitu pelayanan kerja, kondisi kerja dan hubungan karyawan.

\section{Konsep Diri.}

Menurut Shavelson (dalam Meilaratri \& Zulkarnain, 2004) konsep diri merupakan hal yang penting artinya bagi kehidupan individu karena pemahahaman mengenai konsep diri akan menentukan dan mengarahkan perilaku dalam berbagai situasi serta menentukan keberhasilan individu dalam hubungannya dengan masyarakat. Menurut Calhuon dan Acocella (dalam Amelia \& Zulkarnain, 2005) konsep diri adalah pandangan pribadi individu terhadap dirinya yang meliputi tiga dimensi yaitu pengetahuan tentang diri, pengharapan mengenai diri dan penilaian tentang diri sendiri.

Menurut Riswandi (2013) konsep diri adalah pemahaman tentang diri sendiri yang timbul akibat interaksi dengan orang lain. Menurut Brooks (dalam Widiarti, 2017) konsep diri adalah pandangan dan perasaan tentang diri kita. Persepsi tentang diri ini bisa bersifat psikologis, sosial dan fisik. Aspekaspek konsep diri berdasarkan teori Berzonsky (dalam Burns, 2002) yaitu aspek fisik, sosial, moral dan psikis. Menurut Steven, Susan dan Ivy (2010) aspek-aspek konsep diri, yaitu attitude, yaitu respon individu pada hal yang disukai dan tidak disukai. Beliefs, yaitu penerimaan akan sesuatu yang dianggap benar oleh seseorang atau persetujuan terhadap ide/pernyataan tertentu. Values, pedoman yang menunjukkan yang baik dan tidak baik sehingga mengarahkan individu dalam bertindak.

\section{Metode Penelitian}

Penelitian yang digunakan adalah penelitian kuantitatif non-eksperimental. Penelitian ini dilakukan di satuan brigade mobile Sumatera Utara yang beralamat di jalan K.H. Wahid Hasyim No. 3i, Medan Baru Kota Medan. Populasi dalam penelitian ini adalah 400 orang. Sesuai dengan table Krejcie dan Morgan maka sampel dalam penelitian ini adalah 196 orang. Teknik pengambilan sampel yang digunakan dalam penelitian ini mengacu pada teknik non probability sampling, yaitu adalah teknik penentuan sampel yang tidak mengenal tahap-tahap yang menggunakan sampling acak Kerlinger (dalam Lucia, 2004).

Untuk mengumpulkan data penelitian yang dibutuhkan, maka digunakanlah instrumen seperti yang tertera di bawah ini:

1. Skala burnout, untuk mengukur tingkat burnout pada anggota peneliti menggunakan alat ukur pengukuran yang bernama The Maslach Burnout Inventory (MBI).

40 | Psychophedia Jurnal Psikologi Universitas Buana Perjuangan Karawang 
2. Skala lingkungan kerja, untuk mengukur lingkungan kerja diukur dengan menggunakan skala lingkungan kerja berdasarkan aspekaspek lingkungan kerja yang didapat dari Stewart and Stewart (1991) yaitu kondisi fisik dan kondisi psikologis lingkungan kerja.

3. Skala konsep diri diukur dengan menggunakan skala konsep diri berdasarkan aspek-aspek konsep diri yang didapat berdasarkan Berzonsky (dalam Burns, 2002) yaitu aspek fisik, sosial, moral dan psikis.

\section{Hasil Penelitian Dan Pembahasan}

Berdasarkan hasil pengujian hipotesis pada uji korelasi Product moment menggunakan SPSS menunjukan bahwa pada variabel lingkungan kerja (X1) nilai koefisien korelasi (rxy) sebesar 0.454 dan nilai signifikansi (p) sebesar $0.000<0.05$. Hal ini menunjukan bahwa terdapat hubungan secara parsial variabel lingkungan kerja (X1) dengan variabel burnout anggota Brimob (Y). Hasil ini menunjukkan bahwa hipotesis pertama yang berbunyi "ada hubungan lingkungan kerja dengan burnout", dapat dinyatakan terbukti kebenarannya. Hubungan lingkungan kerja (X1) dengan burnout anggota Brimob (Y) menunjukkan arah negatif, artinya semakin baik lingkungan kerja maka semakin rendah burnout anggota Brimob. Dalam hal ini lingkungan kerja di brigade mobile kepolisian daerah Sumatera Utara berhubungan negatif dengan burnout anggota Brimob. Dengan koefisien korelasi (rxy) sebesar 0.454 yang memiliki arti bahwa kekuatan hubungan lingkungan kerja dengan burnout sebesar $45.4 \%$.

Baron dan Greenberg (1995) menjelaskan bahwa burnout yang dialami seorang pekerja selain dipengaruhi oleh faktor internal juga dipengaruhi oleh faktor eksternal dalam organisasi, salah satunya lingkungan kerja. Lingkungan kerja merupakan segala sesuatu yang ada disekitar pekerja sewaktu menjalankan tugas yang dibebankan. Lingkungan kerja adalah keadaan di sekitar tempat kerja pada waktu karyawan melakukan pekerjaannya. Keadaan tersebut dapat mempengaruhi kesejahteraan karyawan sehingga karyawan akan berusaha untuk menghasilkan sesuatu. Lingkungan kerja yang baik akan membawa pengaruh yang baik kepada para karyawan, pimpinan, dan hasil pekerjaannya (Anorogo \& Widiyanti, 1990). Hasil penelitian ini menujukan bahwa anggota Brimob yang merasakan memiliki lingkungan kerja yang tergolong baik, terdapat 101 anggota Brimob atau sekitar $51.53 \%$ yang merasakan lingungan keja pada kategori baik. Sementara 95 orang atau sekitar $48.47 \%$ anggota Brimob merasakan lingkungan kerja yang tergolong sedang.

Menurut Wineman (dalam Syafika, 2004) menyatakan bahwa setiap lingkungan kerja selalu meliputi kondisi lingkungan fisik dan lingkungan psikologis. Lingkungan fisik merupakan keadaan ruangan beserta perlengkapan yang mendukung, sedangkan lingkungan psikologis merupakan kondisi organisasi dan interaksi sosial di dalamnya. Wesik (dalam Syafika, 2004) menyebutkan bahwa lingkungan psikologis adalah keadaan sekitar tempat kerja pada waktu individu melakukan pekerjaan dan kecenderungan ini merupakan keadaan yang dapat mempengaruhi kesejahteraan individu, sehingga individu akan berdaya guna untuk menghasilkan sesuatu.,dan kapasitas kerja yang tinggi sehingga menghasilkan kinerja yang tinggi dan terhindar darikejenuhan dalam bekerja. Hal senada juga dikemukan. 
Schaufeli dan Buunk (1996) menyebutkan lingkungan kerja sebagai faktor yang mempengaruhi terjadinya burnout. Menurut Isyandi (2004) lingkungan kerja adalah sesuatu yang ada di lingkungan para pekerja yang dapat mempegaruhi dirinya dalam menjalankan tugas seperti temperatur, kelembapan, ventilasi, penerangan, kegaduhan, kebersihan tempat kerja dan memadai tidaknya alat-alat perlengkapan kerja. Menurut Stewart and Stewart (1991) yaitu kondisi fisik dan kondisi psikologis lingkungan kerja.

Selain faktor lingkungan kerja, burnout juga berhubungan dengan konsep diri. Asumsi tersebut didukung dengan hasil analisis data yang ditunjukkan oleh koefisien korelasi (rxy) dengan nilai signifikansi (p) $0.000<0,05$. Dan koefisien korelasi (rxy) sebesar 0.364. Sehingga dapat disimpulkan bahwa ada hubungan konsep diri dengan burnout pada anggota Brimob. Dari hasil penelitian ditemukan Koefisien korelasi (rxy) sebesar -0.453 dan yang memiliki arti bahwa kekuatan hubungan konsep diri dengan burout sebesar $45.3 \%$.

Menurut Shavelson (dalam Meilaratri \& Zulkarnain, 2004) konsep diri merupakan hal yang penting artinya bagi kehidupan individu karena pemahahaman mengenai konsep diri akan menentukan dan mengarahkan perilaku dalam berbagai situasi serta menentukan keberhasilan individu dalam hubungannya dengan masyarakat. Menurut Calhuon dan Acocella (dalam Amelia \& Zulkarnain, 2005) konsep diri adalah pandangan pribadi individu terhadap dirinya yang meliputi tiga dimensi yaitu pengetahuan tentang diri, pengharapan mengenai diri dan penilaian tentang diri sendiri.
Menurut Riswandi (2013) konsep diri adalah pemahaman tentang diri sendiri yang timbul akibat interaksi dengan orang lain. Konsep diri merupakan faktor yang menentukan (determinan) dalam komunikasi kita dengan orang lain. Menurut Brooks (dalam Widiarti, 2017) konsep diri adalah pandangan dan perasaan tentang diri kita. Persepsi tentang diri ini bisa bersifat psikologis, sosial dan fisik.

Hasil penelitian ini menunjukan anggota Brimob yang memiliki konsep diri rendah ada sebanyak 2 orang tau sekitar 1.02 $\%$, sementara yang memiliki konsep diri sedang terdapat sebanyak 85 orang atau sekitar $43.36 \%$ dan yang memiliki konsep diri tinggi sebanyak 109 orang atau sekitar $56.62 \%$. Sehingga secara keselurruhan dapat disimpulkan bahwa konsep diri anggota Brimob dalam kategori sedang.

Hughes, Galbraith dan White (2011) yang juga mengatakan bahwa konsep diri merupakan deskripsi mengenai diri sendiri yang juga mengandung evaluasi terhadap diri. Baumeister (dalam Lawrence \& Vimala, 2013) mendefinisikan konsep diri sebagai keyakinan individu tentang dirinya sendiri, termasuk atribut orang lain, siapa dan apa diri itu.

Secara bersamaan hasil penelitian ini menunjukan bahwa ada hubungan antara lingkungan kerja dan konsep diri dengan burnout pada anggota Brimob, hal ini didukung dengan hasil analisis data yang ditunjukkan oleh nilai signifikansi (p) sebesar $0.000<0.05$. Sedangkan nilai koefisien korelasi $(\mathrm{rxy})=0.560$. Burnout merupakan perubahan sikap dan perilaku dalam bentuk reaksi menarik diri secara psikologis dari pekerjaan, seperti menjaga jarak dari orang lain maupun bersikap sinis dengan mereka, membolos, sering terlambat dan keinginan pindah kerja sangat kuat. Hal ini terjadi 
dikarenakan perusahaan atau organisasi tidak memikirkan kualitas kehidupan kerja para karyawannya, berupa kenyamanan baik secara psikologis maupun fisik yang harus didapatkan oleh para karyawan atau pekerjanya. Apabila hal tersebut tetap terjadi, tidak hanya di dalam kehidupan bekerja saja yang akan mengalami permasalahan yang dipengaruhi oleh burnout, tetapi di dalam kehidupannya sehari-hari terutama hubungan dengan teman dan keluarganya akan mengalami kesenjangan atau masalah yang disebabkan dari perubahan atau goncangan emosi di dalam diri seorang pekerja yang mengalami burnout.

Penelitian yang dilakukan oleh Sari (2015) menemukan bahwa semakin tinggi tingkat burnout karyawan maka akan menurunkan daya semangat kerja karyawan pada perusahaan. Selanjutnya Penelitian Ramadhoni dkk (2015) mengungkapkan bahwa tingginya burnout pada karyawan akan berpengaruh pada cara karyawan bekerja dalam perusahaan. Aspek-aspek burnout dalam penelitian ini menggunakan aspek-aspek berdasarkan Maslach (dalam Dorman, 2003) yaitu Emotional exhaustion, Depersonalitation, Low personal accomplistment. Dalam penelitian ini untuk mengukur burnout digunakan alat ukur pengukuran yang bernama The Maslach Burnout Inventory (MBI).

Faktor yang mempengaruhi burnout adalah lingkungan kerja. Schaufeli dan Buunk (1996) menyebutkan lingkungan kerja sebagai faktor yang mempengaruhi terjadinya burnout. Menurut Isyandi (2004) lingkungan kerja adalah sesuatu yang ada di lingkungan para pekerja yang dapat mempegaruhi dirinya dalam menjalankan tugas seperti temperatur, kelembapan, ventilasi, penerangan, kegaduhan, kebersihan tempat kerja dan memadai tidaknya alat-alat perlengkapan kerja. Menurut Stewart and Stewart (1991) yaitu kondisi fisik dan kondisi psikologis lingkungan kerja.

Kondisi fisik lingkungan kerja adalah kondisi fisik dari lingkungan kerja di sekitar karyawan sangat perlu diperhatikan oleh pihak badan usaha, sebab hal tersebut merupakan salah satu cara yang dapat ditempuh untuk menjamin agar karyawan dapat melaksanakan tugas tanpa mengalami gangguan. Memperhatikan kondisi fisik dari lingkungan kerja karyawan dalam hal ini berarti berusaha menciptakan kondisi lingkungan kerja yang sesuai dengan keinginan dan kebutuhan para karyawan sebagai pelaksanan kerja pada tempat kerja tersebut. Kondisi psikologis dari lingkungan kerja, yaitu rancangan fisik dan desain dari pekerjaan, sejumlah ruangan kerja yang tersedia dan jenis-jenis dari perlengkapan dapat mempengaruhi perilaku pekerja dalam menciptakan macam-macam kondisi psikologi. Hubungan terhadap teman sekerja dan hubungan terhadap pimpinan.

Faktor lain yang mempengaruhi burnout adalah konsep diri. Menurut Calhoun dan Acocella (2002) konsep diri adalah pandangan pribadi indvidu terhadap dirinya yang meliputi tiga dimensi yaitu pengetahuan tentang diri, pengaharapan mengenai diri dan penilaian tentang diri sendiri. Agustina (2009) menyatakan konsep diri merupakan gambaran yang dimiliki seseorang tentang dirinya yang dibentuk melalui pengalaman-pengalaman yang diperoleh dari interaksi dengan lingkunganya. Aspek-aspek konsep diri Menurut Berzonsky (dalam Burns, 2002) adalah aspek fisik, sosial, moral dan psikis. 
Aspek fisik, yaitu penilaian individu terhadap segala sesuatu yang dimilikinya. Aspek sosial, yaitu bagaimana peranan sosial yang dimainkan oleh individu dan sejauhmana penilaian dirinya terhadap keluarga, masyarakat dan pekerjaannya. Aspek moral, yaitu nilai-nilai dan prinsipprinsip yang memberi arti dan arah bagi kehidupan kehidupan seseorang. Aspek psikis, yaitu pikiran, perasaan dan sikap individu terhadap dirinya sendiri.

Dari hasil penelitian ini maka ditemukan tingkat burnout pada anggota Brimob Polda Medan terdapat sekitar 1 orang atau sebanyak 1\%, yang mengalami burnout dalam tingkat rendah dan sebanyak 100 orang atau sebesar $51 \%$, yang mengalami burnout dalam kategori sedang dan sebanyak 95 orang atau sebanyak $48 \%$ anggota mengalami burnout dalam kategori tinggi.

\section{Kesimpulan}

Berdasarkan hasil yang telah diperoleh dalam penelitian ini, maka dapat disimpulkan hal-hal sebagai berikut:

1. Ada hubungan positif yang signifikan antara lingkungan kerja dan dengan burnout pada anggota satuan brigade mobile kepolisian daerah Medan Sumatera Utara.

2. Ada hubungan positif yang signifikan antara konsep diri dengan burnout pada anggota satuan brigade mobile kepolisian daerah Medan Sumatera Utara.

3. Ada hubungan positif yang signifikan antara lingkungan kerja dan konsep diri dengan burnout pada anggota satuan brigade mobile kepolisian daerah Medan Sumatera Utara.

4. Hasil lain diperoleh dari penelitian ini, yakni diketahui bahwa subjek penelitian ini yaitu anggota satuan brigade mobile kepolisian daerah Medan Sumatera Utara, memiliki burnout yang tergolong rendah, lingkungan kerja yang kondusif, dan konsep diri yang juga tergolong tinggi.

\section{Kepustakaan}

Amelia, A., \& Zulkarnain. 2005. Konsep diri dan tingkat burnout pada karyawan yang bekerja di instansi pelayanan masyarakat. Psikologika, 9, (10), 4149.

Arikunto, S. 2007. Prosedur penelitian, suatu pendekatan praktik. Jakarta: Renika Cipta.

Baron, K., \& Greenberg. 2003. Behavior in organization understanding and managing the human side of work. 5th Edition. USA: Prentice Hall.

Bernardin, J. H. 1990. Human resources management: An experiental approach. Singapore: McGraw-Hill Book.

Burns, R. B. 2002. Konsep diri (Teori, pengukuran, perkembangan dan prilaku). Jakarta: Arcan.

Calhoun, J. F., \& Acocella, J.R. 2002. Psychology of adjusment and human relationship. New York: Mc Graw Hill, Inc.

Cooper, C. N., Schabarcq, M. J., \& Winnubst, J. A. M. 1996. Handbok of work and heath psychology. United States: John Wiley \& Sons Ltd.

Dariyo, A. 2007. Psikologi perkembangan anak tiga tahun pertama (psikologi atitama). Bandung: Refika Aditama.

Dayakisni. \& Hudaniyah. 2003. Psikologi sosial. Malang: UMM Press.

Dorman, J. 2003. Testing a model burnout for teacher. Australia Journal of Educational and Developmental Psychology, 03, 35-47. 
Eltayef, G. M. 2014. Burnout, self- concept and their relationship to job satisfaction among nurses in Libya. Thesis.

Ema, A. 2004. Peranan dimensi-dimensi birokrasi terhadap burnout pada perawat rumah sakit di Jakarta. Jurnal Psyche, 1, (1).

Ghozali, I. 2012. Aplikasi analisis multivariate dengan program IBM SPSS 20. Semarang: Badan Penerbit Universitas Diponegoro.

Hendriati, A. 2006. Psikologi perkembangan (pendekatan ekologi kaitannya dengan konsep diri dan penyesuaian diri pada remaja). Bandung: PT. Refika Aditama.

Hurlock, B. 2005. Psikologi perkembangan anak jilid 2. Jakarta: Erlangga.

Hughes, A. D., Galbraith. White, D. 2011. Perceived competence: A common core for self-efficacy and self-concept.

Indilusiantari, V., Meliana, I. 2015. Faktorfaktor yang berhubungan dengan burnout syndrome pada pegawai di direktorat Bina kesehatan kerja dan olahraga kementerian kesehatan republik Indonesia Jakarta Selatan tahun 2015. Jurnal Ilmiah Kesehatan, 7, (1), 28-33.

Isyandi, B, 2004. Manajemen sumber daya manusia dalam perspektif global. Pekanbaru: Unri Press

Josephine, A., \& Harjanti, D. 2017. Pengaruh lingkungan kerja terhadap kinerja karyawan pada bagian produksi melalui motivasi kerja sebagai variabel intervening pada PT. Trio Corporate Plastic (Tricopla). AGORA, 5, (3).

Lawrence, A. S. A., Vimala, A. 2013. Selfconcept and achievement motivation of high school students. Conflux Journal of Education, 1, (1), 141-205.
Mangkunegara. A. P. 2005. Sumber daya manusia perusahaan. Bandung: Remaja Rosdakarya.

Maslach, C., \& Goldberg, J. 1998. Prevention of burnout: New perspective. Apply and Preventive Psychology, 7, 63-74.

Meilaratri, B., \& Zulkarnain. 2004. Konsep diri dan kecenderungan pengambilan keputusan dalam membeli pakaian pada remaja wanita. Insight, 2, (1), 10-16.

Nitisemito, A. S. 1992. Manajemen dan sumber daya manusia. Yogyakarta: BPFE UGM.

Noah, Y., \& Steve, M. 2012. Work environment and job attitude among employees in a Nigerian work organization. Journal of Sustainable Society, 1, (2), 36-43.

Nwafor, C. E., Immanuel, E. U., ObiNwosu, H. 2015. Does nurses' selfconcept mediate the relationship between job satisfaction and burnout among Nigerian nurses. International Journal of Africa Nursing Sciences, 3, 71-75.

Pangastiti, N. K. 2011. Analisis pengaruh dukungan sosial keluarga terhadap burnout pada perawat kesehatan di Rumah Sakit Jiwa.

Priyatno, D. 2012. Cara kilat belajar analisis data dengan SPSS 20. Yogyakarta: Penerbit Andi.

Rakhmat, J. 2004. Psikologi komunikasi. Bandung: PT. Remaja Rosdakarya.

Riswandi. 2013. Psikologi komunikasi. Yogyakarta: Graha Ilmu.

Robin, S. P. 2010. Organization behavior. New York: Prentice Hall.

Romadhoni, L. C., Asmony, T., Suryatni, M. (2015). Pengaruh beban kerja, lingkungan kerja, dan dukungan sosial terhadap burnout pustakawan di kota 
Mataram. KHIZANAH AL-HIKMAH, 3, (2), 125-145.

Rosyid, H. F., \& Farhati, F. 1996. Karakteristik pekerjaan, dukungan sosial dan tingkat burnout pada nonhuman service corporation. Jurnal Psikologi, 1, (3), 1-12.

Saktya, A., \& Agustina, Y. M. 2009. Harga diri dan kecenderungan narsisme pada pengguna friendster. Jurnal Psikologi, 3, (1).

Sari, N. L. P. D. Y. 2015. Hubungan beban kerja terhadap burnout syndrome pada perawat pelaksana ruang intermediet RSUP Sanglah. Jurnal Dunia Kesehatan, 5, (2), 8792.

Schaufeli, W. B., \& Buunk, B.P. 1996. Professional burnout. Handbook of Work and Healthy Psychology. New York: John Wiley \& Son Ltd. Schiffman. \& Kanuk. 2004. Perilaku konsumen. Edisi 7. Jakarta: Prentice Hall.

Simanjuntak, P. J. 2003. Produktivitas kerja pengertian dan ruang lingkupnya. Jakarta: Prisma.

Steven B. A., Susan, B. J., \& Ivy, D. K. 2010. Communication principles for a lifetime. Boston: Pearson Education, Inc.

Stewart, C.D., \& Stewart, A. L. 1991. The Medical outcomes survey social support survey. Social Science and Medicine, 32, 705-714.
Syafrika, I., Suyasa, T. 2004. Persepsi terhadap Lingkungan Fisik Kerja dan Dorongan Berperilaku Agresif pada Polisi Lalu Lintas. Insan, 6, (3).

Swasti, K. G., Ekowati, W., Rahmawati, E. 2017. Faktorfaktor yang mempengaruhi burnout pada wanita bekerja di kabupaten Banyumas. Jurnal Keperawatan Soedirman, 12, (3), 190-198.

Taiwo, A. S. 2010. The influence of work environment on worker's productivity: A case of selected oil and gas Industry in Lagos, Nigeria. African Journal of Business Management, 4, (3), 299307.

Tetrich. \& Quich. 2002. Job related burnout, occupational health psychology. USA: American Assosiation Psychology

Widiarti, P. W. 2017. Konsep diri (self-concept) dan komunikasi interpersonal dalam pendampingan pada siswa SMP se-kota Yogyakarta. Informasi Kajian Ilmu Komunikasi, 47, (1), 135-148. 